\title{
UNIVERSITY OF PENNSYLVANIA RADIOCARBON DATES VIII
}

\author{
ROBERT STUCKENRATH, JR. and ELIZABETH K. RALPH
}

Department of Physics and University Museum University of Pennsylvania, Philadelphia 4, Pennsylvania

\section{INTRODUCTION}

This date list includes those series of archaeologic samples completed in this laboratory during 1963 and 1964. The B.P. ages are calculated from A.D. 1950, and are based upon a half-life value of $5568 \mathrm{yr}$. Errors quoted do not include the half-life error. All samples have been pretreated with $3 \mathrm{~N} \mathrm{HCl}$, and some, where noted, have received an additional $2 \% \mathrm{NaOH}$ pretreatment for the removal of possible humic acid contaminants.

Standard calibration samples are 110- to 125-yr old oak samples which, when corrected for age, have $\mathrm{C}^{14}$ contents equal to $95 \%$ of the NBS oxalic acid standard. The $\mathrm{C}^{13}$ relationship between the oak standard and NBS limestone standard \#20 is $-25.7 \pm 1.3$ mils as measured on the University of Pennsylvania mass spectrograph.

We should like to thank John Gruninger and Daria Lissy for their excellent work in the preparation and counting of these samples.

\section{SAMPLE DESCRIPTIONS}

I. ARCHAEOLOGIC SAMPLES: NEAR EAST

\section{A. Iran}

\section{Ziwiyeh series, Iran}

Ziwiyeh $\left(36^{\circ} 15^{\prime} \mathrm{N}\right.$ Lat, $46^{\circ} 20^{\prime} \mathrm{E}$ Long), is ca. $15 \mathrm{mi} \mathrm{E}$ of Saqqez in Kurdistan, Iran. Typologically, the Ziwiyeh materials most closely parallel Hasanlu IIIB ( 7 th to 6th centuries B.c.) with some carry-overs from IV (9th century B.c.). Site may have dated in large part from 7 th or even 8th centuries B.C. Samples dated here come from last phase of major occupation, excavated partially in 1964 by the Hasanlu Project of Univ. Mus., Univ. of Pennsylvania. Additionally, the Ziwiyeh material may provide terminal date for late stage of Zendan-i-Suleiman (Takht-i-Suleiman) where imported Ziwiyeh pottery has been found; prior age estimates of that site have been based upon typological parallels with Ziwiyeh and Hasanlu (Dyson, 1963; Naumann et al., 1962; Pennsylvania III, VI). Coll. 1964 and subm. by R. H. Dyson, Jr., director of the joint expedition of Univ. Mus., Univ. of Pennsylvania, Metropolitan Mus. of Art of New York City, and Archaeol. Service of Iran.

\section{P-873. Terminal occupation}

$2486 \pm 54$

536 в.C.

Charcoal and fine ash from Stratum 3, Area 2, in level of terminal occupation. Estimated date is $600 \pm 50$ B.C.

\section{P-875. Terminal occupation, chimney}

Charcoal and ash from chimney area in level of terminal occupation. Estimated date is $600 \pm 50$ B.C. 


\section{P-872. Terminal occupation, corridor}

Charcoal and soil from corridor, Stratum 3, Area 1, in level of terminal occupation. Estimated date is $600 \pm 50$ B.c.

\section{Arpachiyah series, Iraq}

\section{B. Iraq}

Arpachiyah $\left(36^{\circ} 20^{\prime} \mathrm{N}\right.$ Lat, $43^{\circ} 12^{\prime} \mathrm{E}$ Long $)$, is a small mound NE of Mosul, Iraq. Cultural material from mound is of Halaf and Obeid Periods, and site is of importance in determining the eastern extent of Halaf materials and their relation to Obeid. Coll. 1954 and subm. by F. R. Matson, Pennsylvania State Univ., University Park, Pennsylvania (Mallowan, 1936).

\section{P-585. Arpachiyah, well}

$8064 \pm 78$

6114 B.c.

Charcoal, ash, and clay from dark soil band in side of the well, $50 \mathrm{~cm}$ below top of well head, from SW face where layer contained charcoal and sherds. NW face at this level contained slag and heavily burned material, and band is believed to represent burning of a house in Mallowan's Level 6.

\section{P-584. Arpachiyah, tholos}

$7027 \pm 83$

5077 в.c.

Charcoal flecks, ash, and clay from dark soil band ca. $8 \mathrm{~cm}$ below top of Mallowan's Level 8, which supported stones of the tholos antechamber.

\section{Nippur series, Iraq}

Nippur $\left(32^{\circ} 07^{\prime} \mathrm{N}\right.$ Lat, $45^{\circ} 10^{\prime} \mathrm{E}$ Long), is large ancient city site in Mesopotamia, Iraq. Samples in this series are from Inanna Temple area which was excavated in four campaigns, 1955-1963, under direction of R. C. Haines, Oriental Inst., Univ. of Chicago. Coll. by D. P. Hansen; subm. by Haines. Elevations listed with each sample refer to an arbitrary datum; surface of area varied from $99.70 \mathrm{~m}$ to $98.00 \mathrm{~m}$ (Haines, 1961; Hansen and Dales, 1962; Pennsylvania VI).

Area NE of central part of Inanna Temple

\section{P-810. Level V, ED II/III, 89.25 m}

Charcoal from Sounding P, Level V, ED II/III, elev. 89.25 m. Coll. 1962. Comment: compare this date and others of this series with P-530, $4672 \pm 72$ (Pennsylvania VI) from Early Protoliterate Period of Inanna Temple area.

Area NE of southern part of Inanna Temple

P-798. Level IXB, ED I, $86.00 \mathrm{~m}$

$$
4145 \pm 59
$$

Charcoal, IT 396, from Level IXB low, ED I, elev. 86.00 m. Coll. 1962.

\section{P-803. Level IXB, ED I, 86.10 m}

2271 B.C. 1962. Comment: $\mathrm{NaOH}$ pretreatment. 
P-801. Level IXA, ED I, $86.90 \mathrm{~m}$ 1963.

Charcoal, IT 395, from Level IXA low, floor, ED I, elev. 86.90 m. Coll.

P-800. Level IXA, ED I, $87.05 \mathrm{~m}$

$4157 \pm 62$

2207 B.c.

Charcoal, IT 395, from Level IXA high, Floor 3, ED I, elev. 87.05 m. Coll. 1962. Comment: $\mathrm{NaOH}$ pretreatment.

P.799. Level IXA, ED I, 87.35 m

$8472 \pm 102$

6522 в.c.

Charcoal and dirt, IT 395, from Level IXA high, Floor 2, kiln, ED I, elev. $87.35 \mathrm{~m}$. Coll. 1962. Comment: date does not agree with others of this series and level.

P-806. Level VIIB, ED II, $89.40 \mathrm{~m}$

$4345 \pm 66$

2395 в.c.

Charcoal, IT 370, from Level VIIB high, floor, ED II, elev. 89.40 m. Coll. 1962. Comment: $\mathrm{NaOH}$ pretreatment.

\section{P-804. Level VIIB, ED II, $89.45 \mathrm{~m} \quad 4095 \pm 52$}

Charcoal, IT 209, from Level VIIB high, floor, ED II, elev, $89.45 \mathrm{~m}$ Coll. 1962.

P-805. Level VIIB, ED II, $89.55 \mathrm{~m}$

$4006 \pm 62$

2056 в.c. 1962.

Charcoal, IT general, from Level VIIB high, ED II, elev. 89.55 m. Coll.

NW part of Inanna Temple

P-809. Level IXB, ED I, 86.55 m

$3945 \pm 62$

1995 в.c.

Charcoal, IT 372, from Level IXB low, floor, ED I, 86.55 m. Coll. 1962. Comment: sample was undersized and date, therefore, is less reliable than others in series.

P-819. Level IXA, ED I, $88.45 \mathrm{~m} \quad 4272 \pm 65$

2322 B.C.

Charcoal, IT 374, from Level IXA high, Floor 1, fireplace, ED I, 88.45 m. Coll. 1962.

P-820. Level IXA, ED I, $87.95 \mathrm{~m}$

$4090 \pm 62$

2140 в.c.

Charcoal. IT 374 from I.evel IXA hioh Flone? FN I daw $8705 \mathrm{~m}$ 
nastic I is $2253 \pm 23$ в.c. (P-798, P-801, P-800, P-809, P-819, and P-820, omitting P.799). Average of dates representing Early Dynastic II is $2184 \pm$ 41 B.c. (P-806, P-804, P-805, and P-807). Transition from Early Dynastic II to $\mathrm{III}$ is represented here by $\mathrm{P}-810,2124 \pm 64$ B.c.

\section{Tell-es-Siwwan series, Iraq}

Tell-es-Siwwan ( $34^{\circ} 25^{\prime} \mathrm{N}$ Lat, $43^{\circ} 45^{\prime} \mathrm{E}$ Long), was Neolithic town near Samarra and Tigris R in Iraq. Coll. 1964 by B. A. es-Soof, director of expedition, Bagdad Mus.: subm. by T. H. Carter, Univ. Mus., Univ. of Pennsylvania. Material recovered from levels sampled may be compared to that from Archaic Hassuna levels at Tell Hassuna in Iraq.

\section{P-855. Pre-level I}

$$
\begin{aligned}
& 7456 \pm 73 \\
& \mathbf{5 5 0 6} \text { в.c. }
\end{aligned}
$$

Charcoal lumps from beneath Level I, on Floor 2 of Room 21, beneath black stones, $3.5 \mathrm{~m}$ below surface. Estimated date is end of 7th millennium B.c.

\section{P-857. Level I}

$$
6808 \pm 82
$$

4858 в.c.

Charcoal lumps from Level I, on floor of Room 39, Building T.11, 3 m below surface, in association with large pieces of plaster fallen from upper layers. Estimated date is end of 7 th millennium B.c.

\section{P-856. Level III}

$$
\begin{aligned}
& 7299 \pm 86 \\
& 5349 \text { в.C. }
\end{aligned}
$$

Charcoal lumps from gypsum pit No. 3, Level III, Floor 3, $1.5 \mathrm{~m}$ below surface. Estimated date is middle of 6th millennium B.c.

\section{P-844. Tell al Rimah, Iraq}

Charcoal and gravel from Tell al Rimah $\left(46^{\circ} 26^{\prime} \mathrm{N}\right.$ Lat, $36^{\circ} 16^{\prime} \mathrm{E}$ Long $)$, $8 \mathrm{mi} \mathrm{S}$ of Tel 'Afar in Sinjar region of northern Iraq, from Floor 5 of palace mound (Mound C). Materials found in Level 1 are estimated at 1300 B.C.; those from Levels 7 and 8 suggest Early Assyrian influences of ca. 1800 B.C. Through ceramic and other parallels with Nuzi and Mitannian materials, Floor 5 is estimated to date ca. 1500 B.c. Coll. 1964 and subm. by T. H. Carter, codirector of joint expedition of Univ. Mus., Univ. of Pennsylvania, and British School of Archaeol. in Iraq.

$\begin{array}{ll}\text { P.724. Ur, Early Dynastic III, Royal Cemetery, Iraq } & 3959 \pm 59 \\ 2009 \text { в.c. }\end{array}$ 
Alaça Hiiyük series, Turkey

$$
\text { C. Turkey }
$$

Alaça Hüyük lies near town of Alaça $\left(40^{\circ} 10^{\prime} \mathrm{N}\right.$ Lat, $34^{\circ} 52^{\prime} \mathrm{E}$ Long), ca. $25 \mathrm{mi} \mathrm{S}$ of Corum in northern Turkey. Coll. 1963 and subm. by H. Z. Koşay, director of expedition, Ethnog. Mus., Ankara, Turkey (Arik, 1937).

\section{$\begin{array}{ll}\text { P-825. Early Bronze level, late phase } & 4540 \pm 56 \\ & \mathbf{2 5 9 0} \text { в.c. }\end{array}$}

Charred cereal grain from burnt stratum in Building Level 5, at end of Early Bronze Period. Estimated date is 2000 to 1600 B.c.

\section{P-826. Early Bronze/Hittite transition $\quad \mathbf{4 2 0 0} \pm \mathbf{5 8}$}

Charred cereal grain from Building Level 5 , immediately below Building Level 4. Estimated date is 2000 to 1600 B.c.

\section{P-824. Early Hittite}

$3744 \pm 61$ 1794 B.c.

Charred textiles found in jar in burnt room in Building Level 4, Early Hittite Period. Estimated date is 1600 B.c.

\section{Çatal Hüyük series, Turkey}

Çatal Hüyük ( $37^{\circ} 06^{\prime} \mathrm{N}$ Lat, $32^{\circ} 08^{\prime}$ E Long), is large neolithic mound near Çumra, $50 \mathrm{~km}$ SE of Konya (alt $1000 \mathrm{~m}$ ), Turkey. Region is driest part of Turkey, with annual rainfall of 30 to $40 \mathrm{~cm}$. Coll. and subm. by James Mellaart, director of excavations (1962, 1963, 1964).

General Comment on Çatal Hüyük series: all samples except P.779 were given additional $\mathrm{NaOH}$ pretreatment. At this site there is evidence for the re-use of construction beams in shrines and houses; therefore, the samples of grain are considered more reliable than those of charcoal from beams and posts.

\section{P-782. Level X, Shrine E.X.1 $\quad 8092 \pm 98$}

Charcoal from hearth in Shrine E.X.1. Coll. 1962. Comment: expected to date final occupation of Level $\mathrm{X}$.

\section{P.779. Level IX, Shrine E.IX.8}

$$
\begin{aligned}
& 8190 \pm 99 \\
& 6240 \text { в.C. }
\end{aligned}
$$

Charcoal specks from floor and fill of room of Shrine E.X.8. Coll. 1962. Comment: expected to date either final occupation of Level IX, or the fill im. mediately following.

\section{P-778. Level VII, House E.VII.24}

$7538 \pm 89$

5588 в.c.

Grain from House E.VII.24. Coll. 1963. Comment: expected to date destruction of this house in Level VII, although grain may be intrusive from above.

\section{P-777. Level VI B, Shrine E.VI.10}

$7704 \pm 91$

5754 в.c.

Charcoal from post in W wall (behind bulls' heads) in Shrine E.VI.10. Coll. 1963. Comment: unless renewed in Level VI A (considered unlikely), expected to date construction of this shrine in Level VI A. 


\section{P-797. Level VI B, House E.VI.28}

Charcoal from corner post in House E.VI.28. Coll. 1962. Comment: expected to date construction of this house and of Level VI B.

P-781. Level VI B, Shrine A.VI.1 storeroom

$7524 \pm 90$

5574 B.C.

Charcoal from roofbeam of storeroom of Shrine A.VI.1. Coll. 1963.

\section{P-770. Level VI B, Shrine A.VI.1}

$7912 \pm 94$

5962 в.c.

Charcoal, oak and juniper (id. by Hans Helbaek, Natl. Mus., Copenhagen), from roofbeam of Shrine A.VI.1. Comment: unless renewed in Level VIA, expected to date construction of shrine in VI B unless it is a used beam from a lower level.

\section{P-827. Level VI A/B, brain}

$7579 \pm 86$ 5629 в.c.

Charred human brain from skull of Skeleton 3, House E.VI.1. Coll. 1963. Comment: necklace of black beads suggests female owner. Skeleton found under central platform where stratification of skeletons indicates that this burial was rather early in the sequence found there; sample probably represents Level VI B, or very early phase of VI A.

\section{P-769. Level VI A, Shrine E.VI.25}

$7505 \pm 93$ $\mathbf{5 5 5 5}$ в.c.

Grain from Shrine E.VI.25. Coll. 1962. Comment: expected to date fire which destroyed Level VI A, several hundred yr before date of P-796, below.

\section{P.772. Level VI A, House E.VI.1}

Charcoal from post in main room of House E.VI.1. Coll. 1961. Comment: expected to date construction of VI A, unless post survived reconstruction of House VI, and thus dates from VI B.

\section{P-776. Level V, House E.V.4}

$7640 \pm 91$ 5690 в.с.

Charcoal from post of House E.V.4. Coll. 1961. Comment: expected to date construction of Level V.

\section{P.775. Level IV, House E.IV.4}

$8037 \pm 96$ 6087 B.c.

Charcoal from center of post in upper floor of House E.IV.4. Coll. 1961. Comment: expected to date construction of Level IV, but is probably somewhat older since sample was taken from center of a large beam which, additionally, may have been a re-used beam.

\section{P-796. Level II, Shrine A.II.1}

$$
7521 \pm 77
$$

Grain from Shrine A.II.1. Coll. 1962. Comment: expected to date destruction of shrine and Building Level II in general. 


\section{Can Hasan series, Turkey}

Can Hasan is Chalcolithic mound near village of Can Hasan $\left(37^{\circ} 16^{\prime} \mathrm{N}\right.$ Lat, $33^{\circ} 22^{\prime} \mathrm{E}$ Long), $13 \mathrm{mi} \mathrm{NE}$ of the Kaza Karaman in south-central Turkey. Since mound lies between Hacilar and Merşin in W half of Konya Plain, it is important in Konya Plain sequence, and its pottery appears to be the immediate successor to that of Çatal Hüyük West (the Early Chalcolithic mound). Coll. and subm. by D. H. French, British Inst. of Archaeol., Ankara (French, 1962, 1963; Kohler and Ralph, 1961; Pennsylvania V).

General Comment on Can Hasan series: compare this sequence with dates from the Late Neolithic and Early Chalcolithic levels at Haçilar: P-314, $7340 \pm 94$; P-313, $7350 \pm 85 ;$ P-316, $7170 \pm 134$; and P-315, $6990 \pm 121$ (Pennsylvania V). See also dates from Çatal Hüyük sequence, this date list. All samples received additional $\mathrm{NaOH}$ pretreatment.

The first six charcoal samples listed below form a series from the burnt fill (probably collapsed remains of the upper story) of a house in Early Chalcolithic period. They are from Can Hasan, Grid R23a, Layer 2B, from SE corner of $\mathrm{W}$ room of House 3, except P-795, which is from $\mathrm{E}$ room.

\section{P-794. Early Chalcolithic, D}

From point D. Coll. 1962.

\section{P-790. Early Chalcolithic, A}

From point A. Coll. 1962.

\section{P-791. Early Chalcolithic, B}

From point B. Coll. 1962.

\section{P-792. Early Chalcolithic, B}

From point B. Coll. 1962.

\section{P-793. Early Chalcolithic, C}

$7033 \pm 89$ 5083 в.C.

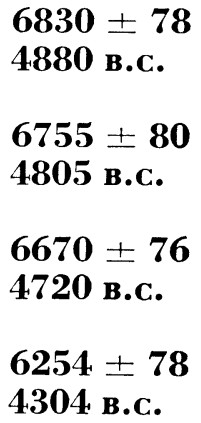

From point C. Coll. 1962. Comment: sample was undersized, and date, therefore, is less reliable than others of this series.

\section{P-795. Early Chalcolithic, E room}

From E room of House 3, ca. 1.5 m below surface. Coll. 1961.

\section{P-789. Middle Chalcolithic \\ $6980 \pm 79$ \\ $\mathbf{5 0 3 0}$ в.C.}

Charcoal from re-occupation level overlying Early Chalcolithic houses. This is Can Hasan Level 2A, and represents early part of Middle Chalcolithic Period. Coll. 1962. Comment: date expected to differ somewhat from others of this series.

\section{P-760. Bronze Age shipwreck, Turkey $\quad 2970 \pm 50$} at at Bes Adalar (Five Islands) group (36 $12^{\prime} \mathrm{N}$ Lat, 30 $27^{\prime} \mathrm{E}$ Long), Cape 
Gelidonya, Turkey. Coll. 1960 and subm. by G. F. Bass, Univ. Mus., Univ. of Pennsylvania (1961). Comment: layer of twigs or brushwood found over interior of hull was presumably cut and put down as cushion for the cargo. Brushwood was probably picked up with the cargo, which came from Cyprus. Estimated date of pottery in cargo is $1200 \pm 50$ в.c. Wood was impregnated with salt and copper corrosion products.

\section{P-788. Gordion City Mound, Turkey}

Sample from outer edge of a cross-section of constructional beam in back wall of Megaron 4, City Mound, Gordion ( $39^{\circ} 45^{\prime} \mathrm{N}$ Lat, $31^{\circ} 55^{\prime} \mathrm{E}$ Long), Turkey. Coll. 1963 by H. N. Michael; subm. by R. S. Young, Univ. Mus., Univ. of Pennsylvania (Kohler and Ralph, 1961; Pennsylvania III, V). Comment: sample represents late phase of Phrygian level before Cimmerian invasion. Burning of 690 to 670 B.C. removed an unknown number of outer growth rings, and sample should pre-date construction of Megaron 4. Compare P-135, $2623 \pm 119 ;$ P-136, $2690 \pm 120$ (Pennsylvania III) ; and P-99, $2660 \pm 118$ (Pennsylvania V), all from City Mound at Gordion.

\section{Jordan}

\section{El-Jib series, Jordan}

El-Jib ( $31^{\circ} 50^{\prime} \mathrm{N}$ Lat, $35^{\circ} 11^{\prime} \mathrm{E}$ Long), ancient Gibeon, lies $12 \mathrm{~km} \mathrm{~N}$ of Jerusalem, Jordan. Coll. and subm. by J. B. Pritchard, director of expedition of Univ. Mus., Univ. of Pennsylvania. Areas and levels mentioned referred to by Pritchard (1964).

\section{P-837. Early Bronze level}

$4501 \pm 65$

2551 в.c.

Charcoal and limestone from Early Bronze level, ref. 10-M-6. Coll. 1962.

\section{P-838. Level 6}

Charcoal and limestone from Level 6, ref. 10-N-4. Coll. 1962.

\section{P-839. Level 6, burnt ceiling}

Charcoal from burnt ceiling, Level 6, ref. 10-N-4. Coll. 1962.

\section{P-840. Room 2}

$3231 \pm 57$

1281 B.c. 1962.

Charcoal and dirt from floor in Room 2, SE corner, ref. 10-M-4/4. Coll.

\section{P-941. Trench below Floor 4}

$3073 \pm 48$

1123 в.C.

Charcoal and limestone from trench below Floor 4, ref. 10-M-3/4. Coll. 1962. Comment: $\mathrm{NaOH}$ pretreatment.

\section{P-843A. Oven room, Floor 4}

$3505 \pm 59$

1555 в.c.

Charcoal from oven room, SE corner, Floor 4, ref. 10-M-3/4. Coll. 1962. Comment: $\mathrm{NaOH}$ pretreatment. 


\section{P-842. Stratum IVA, Middle Bronze}

Charcoal and limestone from Stratum IVA, associated with Middle Bronze pottery, ref. 15-K-18. Coll. 1960. Comment: $\mathrm{NaOH}$ pretreatment.

\section{Tell es-Sa'idiyeh series, Jordan}

Tell es-Sa'idiyeh ( $32^{\circ} 16^{\prime} \mathrm{N}$ Lat, $35^{\circ} 35^{\prime} \mathrm{E}$ Long), lies ca. $2 \mathrm{~km} \mathrm{E}$ of Jordan R, immediately to $\mathrm{S}$ of Wadi Kufrinje, in Jordan. Coll. 1964 during excavation of higher mound and subm. by J. B. Pritchard, director of expedition of Univ. Mus., Univ. of Pennsylvania. Samples are from floors within a complex of dwellings believed, on basis of tentative estimate for date of pottery, to have been destroyed during 8th century B.c.

\section{P-831. Below street pavement}

Charcoal, sand, and limestone, from street, just below pavement, ref. 23-G-6. Comment: $\mathrm{NaOH}$ pretreatment.

\section{P-830. Street, level with Floor 2}

$$
\begin{gathered}
2572 \pm 59 \\
622 \text { B.C. }
\end{gathered}
$$

Charcoal and limestone, from street with level of Floor $2,25 \mathrm{~cm}$ above pavement, ref. 23-G-6.

\section{P-834. Floor 2, column}

$$
2726 \pm 157
$$

Charcoal from beside column, Floor 2, ref. 23-D-4. Comment: $\mathrm{NaOH}$ pretreatment.

\section{P-833. Floor 2, Room 2}

Mildewed charcoal, sand, and limestone from Room 2, Floor 2, ref. 23-G-5.

\section{P-835. Floor 2, Room 1}

Charcoal and limestone from Room 1, Floor 2, ref. 23-D-5.

P-832. Floor 2, wall B
$2418 \pm 54$

468 в.c.

$2406 \pm 52$

456 в.C.

Mildewed charcoal, sand, and limestone from Floor 2, just $\mathrm{N}$ of wall $\mathrm{B}$, ref. 23-D-6.

\section{P-829. Above Floor 2}

$2596 \pm 56$

Charcoal, sand, and dirt from above Floor 2, ref. 23-C-4.

\section{P-836. Above floor, roof beam}

646 в.c.

Charcoal from roofbeam, dirt, and limestone from above Floor 2, ref. 23-C-3.

$$
\text { E. Egypt }
$$

\section{P.725. Cheops boat, Giza, Egypt}

Pieces of Cedrus, Zizyphus, and Cupressus from Cheops boat found in closed pit carved in rock behind Great Pyramid at Giza $\left(30^{\circ} \mathrm{N} \mathrm{Lat}, 31^{\circ} \mathrm{E}\right.$ 
Long), Egypt. Coll. 1955 and subm. by Zaky Iskander, Director, Chem. Lab.. Dept. of Antiquities, Cairo. Comment: estimated "historical" date is 2650 в.c. (Iskander, personal commun., Feb. 7, 1964).

P-726. Tomb of Tutankhamon, Egypt

Pieces of Cedrus libani and Zizyphus spina Christi from coffin of Tutankhamon (18th dynasty), Valley of the Kings ( $25^{\circ} 40^{\prime} \mathrm{N}$ Lat, $32^{\circ} 30^{\prime} \mathrm{E}$ Long). Thebes, Egypt, which is now in Egyptian Mus., Cairo; date of transfer to mus. is unknown. Excavated by Howard Carter (Carter and Mace, 1923). Subm. by Iskander. Comment: estimated "historical" date is 1343 B.C. (Iskander, personal commun., Feb. 7, 1964).

\section{Soleb Necropolis series, Sudan}

$$
\text { F. Sudan }
$$

Soleb Necropolis ( $20^{\circ} 26^{\prime} \mathrm{N}$ Lat, $30^{\circ} 20^{\prime} \mathrm{E}$ Long), lies ca. $1 \mathrm{~km} \mathrm{~W}$ of Nile $\mathrm{R}$ in the Sudan. Samples, with estimated dates ranging from Predynastic to Meroitic periods, were coll. 1960; subm. by M. Schiff Giorgini, Univ. of Pisa, Rome. (Necropolis is described by Giorgini, 1958; tomb excavations by Giorgini, 1959).

\section{P.721. Predynastic Period, no. 12}

$$
\begin{aligned}
& 6195 \pm 70 \\
& 4245 \text { в.c. }
\end{aligned}
$$

Charcoal found on surface in $\mathrm{E}$ embellishment of necropolis in small hole hollowed out of rock, and believed to be of predynastic age, earlier than 3000 B.C. Coll. by Cl. Robichon.

\section{P-722. Predynastic Period, no. 13}

$$
6126 \pm 70
$$

4176 B.c.

Charcoal from same locus as P-721, above. Coll. by Cl. Robichon. Comment: $\mathrm{NaOH}$ pretreatment.

\section{P-717. Tomb 12, no. 6}

$3111 \pm 59$

1161 B.C.

Charcoal from Tomb 12, from surface above a burial at level estimated to be of Thoutmosis III to Amenophis III periods, 1500 to 1370 B.C. Coll. by M. Schiff Giorgini. Comment: $\mathrm{NaOH}$ pretreatment. Some dust and mildew present. brushed off before pretreatment.

P-718. Tomb, no. 7

$$
\mathbf{3 0 8 7} \pm \mathbf{5 9}
$$

1137 B.c.

Charcoal from burial chamber of tomb dated archaeologically to reign of Amenophis III, 1408 to 1372 в.c. Coll. by M. Schiff Giorgini.

P-720. Tomb 37, no. 9

$2981 \pm 58$

1031 B.c.

Wood from sarcophagus found in underground chamber of Tomb 37, ca. 4 m deep. Sarcophagus may date from end of 18th dynasty (1370 to 1314 B.c.) or, more likely, from 19th dynasty (1314 to 1200 B.c.). Coll. by Cl. Robichon. Comment: $\mathrm{NaOH}$ pretreatment.

\section{P-714. Tomb 32, no. 3}

$$
3045 \pm 66
$$

Charcoal from mixed samples of charcoal, bone, and connective tissue 
from $3 \mathrm{~m}$ level of disturbed pit of Tomb 32, extending $4 \mathrm{~m}$ deep. Scarabs of Rameses period ( 1300 to 1100 в.c.) were found at this level. Coll. by $\mathrm{Cl}$. Robichon.

General Comment, P-714, P-716, P.712, P.715: while scarabs of Rameses period were found at this level, it is possible that the fire itself may have occurred either at this time, or at some later period. Note also comparison of sample materials from this level in Tomb 32: P.714 and P.715, unidentified charcoal; P.716, charred palm wood; P.712, charred human bone.

\section{P-716. Tomb 32, no. 5}

$2964 \pm 59$

1014 B.c.

Charred palm wood from same locus as P-714, above. Coll. by Cl. Robichon. Comment: $\mathrm{NaOH}$ pretreatment.

\section{P.712. Tomb 32, no. 1}

$$
2929 \pm 66
$$

Charred human bone from same locus as P-714 and P-716, above. Coll. by Cl. Robichon. Comment: pre-charred in nitrogen atmosphere before $\mathrm{HCl}$ pretreatment.

\section{P-715. Tomb 32, no. 4}

$2888 \pm 127$

938 в.с.

Charcoal from same locus as P-714, P-716, and P-715, above. Coll. by Cl. Robichon. Comment: $\mathrm{NaOH}$ pretreatment.

\section{P.723. No. 14}

$3053 \pm 59$

1103 в.c.

Uncharred human bones from $2 \mathrm{~m}$ level of an undisturbed shallow pit attributed to Meroitic period (ca. Christian era). Coll. by Cl. Robichon. Comment: pre-charred in nitrogen atmosphere before $\mathrm{HCl}$ pretreatment. Analysis indicated carbon content of $4.6 \%$ before $\mathrm{HCl}$ pretreatment, but without nitrogen pyrolysis.

II. ARCHAEOLOGIC SAMPLES: ITALY

\section{P-579. Sybaris, Italy}

$$
2602 \pm 45
$$

Charcoal from plain of Sybaris ( $39^{\circ} 43^{\prime} \mathrm{N}$ Lat, $16^{\circ} 33^{\prime} \mathrm{E}$ Long), Cosenza, Italy, from Test Pit A, ca. $6 \mathrm{~m}$ deep. Sample was found in association with potsherds of 6th and 7th centuries B.c., both in grey clay under clay. Coll. 1962 by D. G. Brown; subm. by E. K. Ralph, Univ. of Pennsylvania (Brown, 1963; Rainey, 1962a, 1962b; Ralph, 1963). Comment: date of $652 \pm 45$ в.c. $(5568$ half-life) or $730 \pm 45$ в.c. ( 5730 half-life) indicates that charcoal is of about same age as potsherds. Thus pottery may have been at this location in Th century B.c., but it is also possible that both charcoal and potsherds were washed together there by river or sea waters. Excavation was made with a drag-line shovel below water table, and stratigraphy is therefore uncertain. Additionally, level was disturbed a few meters from sample location by a well installation during Roman times. 
III. ARCHAEOLOGIC SAMPLES: BRAZIL

\section{Sambaqui de Saquarema series, Brazil}

Sambaqui de Saquarema $\left(25^{\circ} 20^{\prime} \mathrm{S} \mathrm{Lat}, 84^{\circ} 45^{\prime} \mathrm{W}\right.$ Long $)$, is shellmound site near Sambaqui de Gomes, $3 \mathrm{~km} \mathrm{~S}$ of Rio Nundiaquara and $650 \mathrm{~m} \mathrm{~N}$ of Saquarema station near NW shore of Bay of Antonia, Paranas, Brazil. Mound measures $90 \mathrm{~m}$ long by $40 \mathrm{~m}$ wide, with original height estimated at $10.5 \mathrm{~m}$; base of mound rests on an old mangrove swamp ca. $2 \mathrm{~m}$ below present water level. Site was excavated 1959-1960 by J. W. Rauth, Univ. of Parana, Brazil; subm. by W. R. Hurt, Indiana Univ., Bloomington, Indiana (Rauth and Hurt, 1960; Hurt, 1962, 1964; Pennsylvania VI).

\section{P-588. Unit C, $8.5 \mathrm{~m}$}

Finely powdered charcoal and shell from Unit C, $8.5 \mathrm{~m}$ deep.

General Comment (W.R.H.): Unit A: from surface to depth of $4.25 \mathrm{~m}$ were thick strata of alternating layers of shells-oyster (Ostrea sp.), berbigoa (Anomolocardia brasiliana) and decomposed Modiolus brasiliensis-and charcoal layers. Unit C: from $4.50 \mathrm{~m}$ to $10.5 \mathrm{~m}$ were thick strata of alternating layers of oyster shells and charcoal lenses, but completely lacking in Anomolocardia, Modiolus, and animal bones.

\section{P-538. Unit C, 8.0 m}

$4071 \pm 73$

Charcoal, ash, and powdered shell from Unit C, $8.0 \mathrm{~m}$ deep.

\section{P-587. Unit C, $6.8 \mathrm{~m}$}

$4307 \pm 69$

2357 в.c.

Finely powdered charcoal and shell fragments from Unit C, $6.8 \mathrm{~m}$ deep.

P-586. Unit A, $2.0 \mathrm{~m}$

$3905 \pm 67$

1955 в.C.

Small lumps of charcoal and shell fragments from Lnit A, $2.0 \mathrm{~m}$ deep.

\section{P-536. Unit A, $1.0 \mathrm{~m}$ to $1.5 \mathrm{~m}$}

$4056 \pm 73$

2106 в.c.

Charcoal, clay, and powdered shell, a combination of two samples, one $1.0 \mathrm{~m}$ deep, the other $1.5 \mathrm{~m}$ deep, both from Unit A.

Date lists:

\section{ReFERENGe}

British Museum III Barker and Mackey, 1961

Pennsylvania III Ralph, 1959

Pennsylvania V Ralph and Stuckenrath, 1962

Pennsylvania VI Stuckenrath, 1963

Arik, R. O., 1937, Les fouilles d'Alaca Hoyuk, enterprises par le Societe d'histoire turque; rapport prelinaire dur les travaux en 1935: Ankara.

Barker, Harold, and Mackey, John, 1961, British Museum natural radiocarbon measurements III : Radiocarbon, v. 3, p. 39-45.

Bass, G. F., 1961, The Cape Gelidonya wreck: preliminary report: Am. Jour. Archaeol., v. 65, p. $267-276$.

Brown, D. F., 1963, The search for Sybaris: 1962: Expedition, Bull., Univ. Mus., Univ. of Pennsylvania, v. 5 , p. $40-47$.

Carter, Harold, and Mace, A. C., 1923, The tomb of Tutankh.Amen, v. 1: London, Cassell 
French, D. F., 1962, Excavations at Can Hasan: first preliminary report, 1961: Anatolian Studies, v. 12, p. 27-40.

1963, Excavations at Can Hasan, second preliminary report, 1962: Anatolian Studies, v. 13, p. $29-42$

Giorgini, M. Schiff, 1958, Soleb, campagna 1957-58: Kush, v. 6, p. 82-98.

1959, Soleb, campagna 1958-59: Kush, v. 7, p. 154-170.

Haines, R. C., 1961, The temple of Inanna at Nippur, the ancient holy city of Sumer: further excavations at this notable site: Illus. London News, v. 239, no. 6371, p. 408411.

Hansen, D. P., and Dales, G. F., 1962, The temple of Inanna, queen of heaven, at Nippur: Archaeology, v. 15, no. 2 , p. 75-84

Hurt, W. R., 1962, New and revised radiocarbon dates from Brazil: W. H. Over Mus., State Univ. of South Dakota, Mus. News, v. 23, no. 11, p. 1-4. v. 30, no. 1 , Recent $25-33$

Kohler, E. L., and Ralph, E. K., 1961, $\mathrm{C}^{14}$ dates for sites in the Mediterranean area: Am. Jour. Archaeol., v. 65, p. 357-367.

Mallowan, M. E. L., 1935, Excavations at Tell Arpachiyah, 1933: Iraq, v. 2, pt. 1.

Mellaart, James, 1962, Excavations at Catal Huyuk: first preliminary report: Anatolian Studies, v. 12, p. $41-65$.

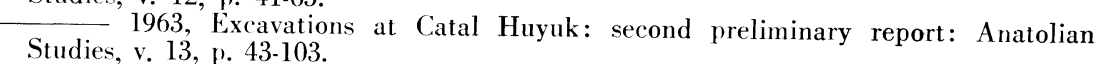

1964, A neolithic city in Turkey: Sci. Am., v. 210, p. 94-104.

Naumann, Rudolf, Leiss, Wolfram, Nylander, Carl, Gezelius, Lars, and Oehler, Hansgeorg, 1962, Takht-i-Suleiman und Zendan-i-Suleiman, Grabungsbericht 1961: Archaolgischer Anzeiger 1962, p. 634-692.

Pritchard, James B., 1964, in press, Winery, defenses and soundings at Gibeon: Mus. Mon., Univ. Mus. (Philadelphia).

Rainey, F. G., 1962a, Electronics to the rescue in the search for the lost city of Sybaris: discoveries of a point U.S.-Italian expedition-Part 2: Illus. London News, v. 241,
no. 6436 , p. $928-931$.

$1962 \mathrm{~b}$, Engineering devices used in the excavation of the lost city of Sybaris: discoveries of a point U.S.-Italian expedition-Part 2: Ullus. London News, v. 241 no. 6437, n. 972-974.

Ralph, E. K., 1959, University of Pennsylvania radiocarbon dates III: Am. Jour. Sci. Radioc. Supp., v. 1, p. 39-45.

1963, Search for a city buried 2700 years: Wellesley Alumnae Mag., v. 47, p. $283-285,310$.

Ralph, E. K., and Stuckenrath, Robert, Jr., 1962, University of Pennsylvania radiocarbon dates V: Radiocarbon, v. 4, p. 144-159.

Rauth, J. W., and Hurt, W. R., 1960, The shellmound of Saquarema, Parana, Brazil: W. H. Over Mus., State Univ. of South Dakota, Mus. News, v. 21, no. 9, p. 1-9.

Stuckenrath, Robert, Jr., 1963, University of Pennsylvania radiocarbon dates VI: Radiocarbon, v. 5, p. 82-103.

Woolley, Sir C. L., 1934, The royal cementery: Ur excavations, v. 2, p. 27, 30, 305-307. 